Brit. J. industr. Med., 1960, 17, 234.

\title{
OBSERVATIONS ON THE OCCUPATIONAL LIFE HISTORY OF THE COAL-FACE WORKER AT TWO COLLIERIES
}

\author{
BY \\ O. P. EDMONDS* and D. S. KERR \\ From the East Midlands Division, National Coal Board
}

(RECEIVED FOR PUBLICATION OCTOBER 1, 1959)

\begin{abstract}
Coal-face work is well known to be arduous and dangerous; it is performed in an unnatural environment even where conditions are good. Few men can continue this work until the age of retirement. They usually seek alternative employment either outside the industry or within the other major occupational groups at a colliery. The latter comprise the surface workers and those employed underground other than at the coal-face. This paper is concerned with those who stay within the industry. From a study of 73 workers who left the coal-face at two collieries, it indicates (1) the extent to which migration to alternative employment occurs each year, and (2) the resultant distribution of ex coal-face workers among these other occupational groups. The length of effective working life of the coal-miner on the coal-face, the reasons which precipitate his leaving it, and the type of work which he is able to do are also described. This information is of economic importance but it is mainly of value in assessing the effects of coal-face work upon the health of the coal-miner.
\end{abstract}

Annual Migration of Workers from the Coal-face

Sources of Information.--Information was derived from two collieries, $A$ and $B$, whose main environmental features are indicated in Table 1. Both collieries are roughly the same depth. Colliery B has thinner seams and far less mechanical loading of the coal. It is also much warmer and subjectively the conditions are more unpleasant.

TABLE 1

MAIN ENVIRONMENTAL FEATURES OF THE COLLIERIES

\begin{tabular}{l|c|c}
\hline & Colliery A & Colliery B \\
\hline $\begin{array}{l}\text { Total average number } \\
\text { employed }\end{array}$ & 1,725 & 1,637 \\
$\begin{array}{l}\text { Number of coal-face } \\
\text { workers }\end{array}$ & 706 & 806 \\
$\begin{array}{c}\text { Depth of shaft (yards) } \\
\text { Return air tempera- } \\
\text { ture }\left({ }^{\circ} \text { F.).: }\right. \\
\text { Dry bulb }\end{array}$ & 750 & 716 \\
$\begin{array}{c}\text { Wet bulb } \\
\text { Type of mining } \\
\text { Seam thickness }\end{array}$ & 74 & 79 \\
\hline
\end{tabular}

Every coal-miner who, during the two years 1957 and 1958, was down-graded from the coal-face at Colliery A, and who, after six months, appeared

*Present Address: North Western Division, National Coal Board. unlikely to return, was interviewed. There were 34 such ex coal-face workers. Two who died while still working on the coal-face during this period, and about whom information was readily available, are also included in this group, making a total of 36.

Information of a similar group at Colliery B is presented for the year 1957 . These numbered 33 which, with four deaths, provided another group of 37 ex coal-face workers. There is in all, therefore, a group of 73 coal-miners who have left the coal-face. Information in respect of the two groups is presented separately, but the emphasis is on the comparable results rather than on minor degrees of variance. Two collieries were used in order to preclude criticism that the results were a local phenomenon. For convenience the information about these 73 ex coal-face workers is expressed as rates per 1,000 coal-face workers.

\section{Extent of Annual Migration from the Coal-face}

In collieries $A$ and $B$ each year 2.7 coal-face workers from each 1,000 on the coal-face died whilst still working on the coal-face. 12.6 left the industry, but as some of these returned later and we have no evidence that they left the coal-face permanently, they are not included in the Tables. 
TABLE 2

NUMBER OF MEN LEAVING COAL-FACE PER ANNUM IN EACH AGE GROUP RELATED TO NUMBER AT RISK

\begin{tabular}{|c|c|c|c|c|c|c|c|c|c|}
\hline \multirow[b]{2}{*}{ Age Group } & \multicolumn{3}{|c|}{ Collieries A and B } & \multicolumn{3}{|c|}{ Colliery A } & \multicolumn{3}{|c|}{ Colliery B } \\
\hline & $\begin{array}{c}\text { No. of } \\
\text { Coal-face } \\
\text { Workers } \\
\text { per Annum }\end{array}$ & $\begin{array}{c}\text { No. } \\
\text { Leaving } \\
\text { Coal-face } \\
\text { per Annum }\end{array}$ & $\begin{array}{c}\text { Rate per } \\
1,000 \\
\text { per Annum }\end{array}$ & $\begin{array}{c}\text { No. of } \\
\text { Coal-face } \\
\text { Workers } \\
\text { per Annum }\end{array}$ & $\begin{array}{c}\text { No. } \\
\text { Leaving } \\
\text { Coal-face } \\
\text { per Annum }\end{array}$ & $\begin{array}{c}\text { Rate per } \\
1,000 \\
\text { per Annum }\end{array}$ & $\begin{array}{c}\text { No. of } \\
\text { Coal-face } \\
\text { Workers } \\
\text { per Annum }\end{array}$ & $\begin{array}{c}\text { No. } \\
\text { Leaving } \\
\text { Coal-face } \\
\text { per Annum }\end{array}$ & $\begin{array}{c}\text { Rate per } \\
1,000 \\
\text { per Annum }\end{array}$ \\
\hline \multirow[t]{2}{*}{$\begin{array}{l}19-24 \\
25-34 \\
35-44 \\
45-54 \\
55-64\end{array}$} & $\begin{array}{l}250 \\
600 \\
605 \\
526 \\
231\end{array}$ & $\begin{array}{r}5 \\
7 \\
14 \\
29 \\
18\end{array}$ & $\begin{array}{l}20 \cdot 0 \\
11 \cdot 6 \\
23 \cdot 1 \\
55 \cdot 1 \\
77 \cdot 9\end{array}$ & $\begin{array}{l}146 \\
356 \\
398 \\
350 \\
156\end{array}$ & $\begin{array}{r}2 \\
3 \\
8 \\
17 \\
6\end{array}$ & $\begin{array}{r}13.7 \\
8.4 \\
20.1 \\
48.6 \\
38.5\end{array}$ & $\begin{array}{r}104 \\
244 \\
207 \\
176 \\
75\end{array}$ & $\begin{array}{r}3 \\
4 \\
6 \\
12 \\
12\end{array}$ & $\begin{array}{r}28 \cdot 8 \\
16 \cdot 4 \\
28 \cdot 8 \\
68 \cdot 1 \\
160 \cdot 0\end{array}$ \\
\hline & 2,212 & $* 73$ & $32 \cdot 9$ & 1,406 & +36 & $25 \cdot 5$ & 806 & $\$ 37$ & 45.9 \\
\hline
\end{tabular}

*Includes six deatbs on coal-face. †Includes two deaths.

¥Includes four deaths.

$30 \cdot 2$ found alternative work within the industry, and we have information of their present work. For every coal-face worker, therefore, who is actually engaged on this work at the time of death each year, 11 others have found alternative work within the other major occupational groups in the industry, either on the surface or elsewhere underground.

\section{Age of Workers on Leaving the Coal-face}

Forty-seven of the 73 ex coal-face workers $(64.4 \%)$ were over the age of 44 , but these figures are best related to the number of coal-face workers in these age-groups. This is expressed in Table 2. Coal-face workers leave the coal-face at all ages (mean age 44.4 years). In the first five years (men aged 19-24) the rate is 20 per 1,000 employed there per annum. This falls to 11.6 for the next 10 years (men aged 25-34) and then the rate doubles to 23.1 for men in the 35-44 age group. For the next 10 years the rate increases by two and a half times to 55.1 per 1,000 and is then 77.9 per 1,000 over the age of 54 . The coal-face worker over 34 is roughly three times more likely to leave the coal-face than the man under this age (44.7 and $14 \cdot 1$ per 1,000 per annum respectively). This emphasizes what one might expect-that coal-face work rejects unfit men at all ages, and more especially the older men.

Both collieries show this same general pattern. The overall rate at Colliery $B$ is higher than that at Colliery A (45.9 and 25.5 per 1,000 respectively). This occurs at all age-groups and is most marked over the age of 54 . This is due partly to the fact that coal-face conditions are much worse at Colliery B, but also to the fact that during 195710 extra posts as training supervisor were made available at this colliery owing to the development of a new training coal-face. These posts are lower paid than coal-face work, but slightly higher than work elsewhere underground. They are attractive and possibly half of the men who took these posts might otherwise have persevered for a little longer on the coal-face. Similar vacancies did not occur at Colliery A.
Number of Years Worked at the Coal-face by those Leaving the Coal-face

The number of years worked at the coal-face is closely related to the age at leaving the coal-face because most coal-face workers start at an early age. Sixty-nine per cent of the group under review were less than 24 years of age when they began work at the coal-face. Fig. 1 indicates the average life at the coal-face in each age-group of coal-miners leaving the face, and demonstrates this point.

The mean life at the coal-face of these 73 ex coalface workers was 21.3 years, but some survived only a few years while the fittest endured 33.3 years. Those 47 who were over 44 years of age on leaving the face averaged 28.4 years of coal-face life, and the 26 aged less than 45 a coal-face life of $8 \cdot 8$ years.

Both collieries demonstrate the same trends, although the mean coal-face life at Colliery A was slightly longer than at Colliery B (21.8 and 21 years). In the younger age-groups, however, the average values are similar and the chief difference lies in the older men. Men can stay on the coal-face longer in mechanized mines. 36.5 years at Colliery $A$ and 31.7 years at Colliery B were spent on the coal-face by those over 54 ; this was partly due to several men at Colliery $B$ who might have stayed a little longer on the coal-face taking training supervisor jobs. As against this at Colliery A ex coal-face workers from neighbouring pits are usually recruited for these jobs, as the older coal-face workers find that they can continue longer on the mechanized coalface.

\section{Factors which Induce Coal-miners to Leave the Coal-face}

Coal-miners tend to stay on the face as long as possible because of pride in their work in addition to its high status value and remuneration. Table 3 indicates the principal factors which cause men to leave the coal-face. It is not surprising that only $12(16.4 \%)$ of the coal-face leavers admitted that the work was too much for them, or that they had had 


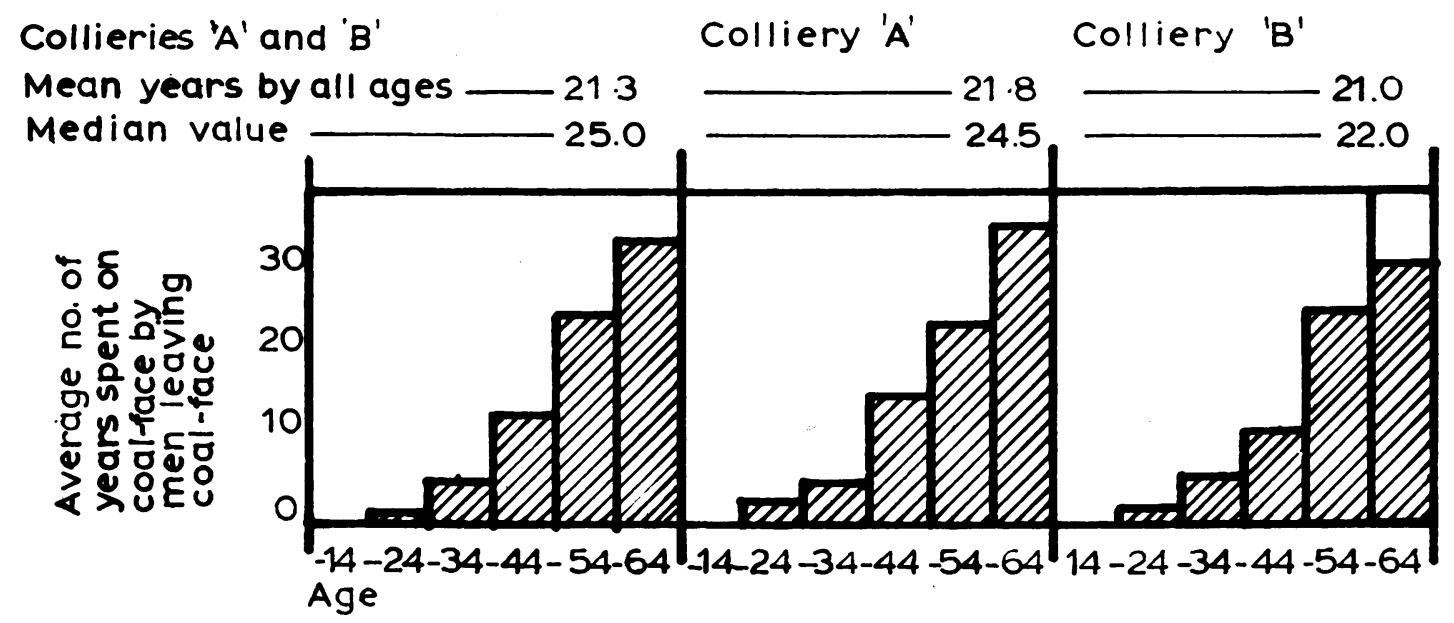

Fig. 1.-Average number of years worked at the coal-face by men leaving the coal-face in each age group.

enough. Against this $30(41.0 \%)$ complained of some incapacitating injury (over half of these were injuries to the back), and $25(34.2 \%)$ of some debilitating illness. The injuries were distributed largely among the younger and the illnesses among the older men. Many had several disabilities, but the one which was thought to be the main factor is classified in Table 3.

TABLE 3

\begin{tabular}{l|c|c}
$\begin{array}{c}\text { Main Factor Causing } \\
\text { Men to Leave Coal-face }\end{array}$ & $\begin{array}{c}\text { No. of } \\
\text { Coal-face Workers }\end{array}$ & $\begin{array}{c}\text { \% of Total } \\
\text { Leaving Coal-face }\end{array}$ \\
\cline { 1 - 2 } Injury & 30 & $41 \cdot 0$ \\
Illness & 25 & $34 \cdot 2$ \\
General fatigue & 8 & $16 \cdot 4$ \\
Voluntary & 4 & $8 \cdot 1$ \\
Death & 6 & $99 \cdot 7$ \\
\hline \multicolumn{1}{|c|}{ Total } & 73 & \\
\hline
\end{tabular}

\section{Alternative Work Undertaken by Workers Leaving the Coal-face}

Table 4 indicates the nature of the work which those coal-miners leaving the face are able to do. Only $20.5 \%$ are performing full-time road maintenance and development work. The trainee supervisors do this work on a part-time basis when there are no trainees, so that, in all, $35.6 \%$ may be said to be able to do moderately heavy work. Although this work is fairly severe on occasions, there is no rigid daily cycle of operation as there is on the coal-face. Many explain that it is the speed of coal-face work which proved so exacting. Over half, however $(52.0 \%)$ were able to do only the lightest of work such as conveyor operator (button job), belt patrol, engine driver or loco driver. A few men find their way to the surface, usually, as general labourers in the yard gang. Surface work is not generally popular with the underground worker. Twenty find alternative work underground for each one going to the surface. Apart from the reduced wages the underground worker misses the companionship of men of similar ilk, for surface work attracts a vastly different type of man.

TABLE 4

\begin{tabular}{l|c|c}
\hline \multicolumn{1}{c|}{ Nature of Alternative Work } & No. of Men & $\%$ of Total \\
\hline Trainee supervisor & 11 & $15 \cdot 1$ \\
Road maintenance and development & 15 & $20 \cdot 5$ \\
Light work & 38 & $52 \cdot 0$ \\
Surface-General labourer (light work) & 3 & $4 \cdot 1$ \\
(Deceased) & $(6)$ & $(8 \cdot 1)$ \\
\hline Total & 73 & $99 \cdot 8$ \\
\hline
\end{tabular}

Distribution of Ex Coal-face Workers Among Others Underground and Surface Workers

As 30.2 from every 1,000 coal-face workers each year found alternative employment among "others underground" and "surface workers", there will be an accumulation over the years of ex coal-face workers in these latter occupational groups. This has been shown by the examination of a random selection of 46 "others underground" and 26 "surface workers" at Colliery A (Edmonds, 1958). Twentyfive of the former $(54.5 \%)$ and six of the latter $(23.0 \%)$ were found to have done some coal-face work. They form a larger proportion of "others underground" in the older age groups $-77.7 \%$ of those over the age of 44 .

Fig. 2 indicates the number with and without coal-face experience in the different age groups of 
the random selection of 46 "others underground", and demonstrates the increasing proportion of the former in the higher age-groups.

This distribution raises a secondary point, namely, whether by selective recruitment more jobs could be made available for ex coal-face workers in these occupational groups. Among the 46 "others underground", 21 had no coal-face experience. Only six of these, however, were doing jobs for which the ex coal-face worker would be suited; the rest were craftsmen. It would seem, therefore, that only six out of 46 (or $13 \%$ ) more jobs among "others underground" could be made available. On the surface, colliery managers expressed surprise that $23 \%$ were ex coal-face workers since recruitment to the surface is for the most part direct. It is not by any means a source of alternative work for underground workers, as in general they dislike surface work.

The distribution of ex coal-face workers amongst "others underground" and on the "surface" indicates the cumulative effect of movement from the coal-face in the past. Such a group is not representative of the total coal-face workers who seek alternative work in the industry each year. These are of all ages initially, but those who left the coalface at an early age will tend to outnumber those who left later, for the latter proportionately retire and die more quickly.

Analysis of this group of 31 ex coal-face workers in the random selection confirms this; $22(70.9 \%)$ had left the coal-face before reaching 45 years of age and their average coal-face life was 16.1 years as would be expected. Injury or illness was the main cause of their leaving the coal-face in $87.0 \%$ and only six $(19.4 \%)$ were still able to perform tasks other than light work. These 31 ex coal-face workers, therefore, closely resemble those younger men who leave the coal-face each year.

\section{Discussion of Results}

Heasman, Liddell, and Reid (1958) analysed the actual occupation at death (which they verified with great thoroughness) of a group of coal-miners. They noted that the mortality ratio for coal-face work was less than that of the coal-miner employed elsewhere underground; they suggested that only a man of good physique undertakes coal-face work, and that if he should become unfit he would be expected to move to lighter work. This limited survey endorses this explanation and shows that for every coal-face worker who dies while employed on the coal-face, 11 transfer to other jobs, mostly elsewhere underground. The majority of these are over 44 years of age and are suffering from some illness or injury. The lower mortality rate for coalface workers is therefore a measure of a robust body of coal-miners who are still able to endure the rigours of coal-face work. The rates for other workers underground may, in fact, reflect the effects of such rigours, for a large proportion of these men have experienced many years at the coal-face. It is suggested, therefore, that useful information about the health hazards of coal-face work might be obtained by a study of other underground workers.

Conversely, it is usual, during investigation, to classify the main occupational groups at a colliery as "coal-face workers", "others underground" and "surface workers" as if they were separate entities. This is satisfactory where the matter pursued is a direct result of the immediate environment, but where previous conditions may be important then the past occupational history must be considered, for example in studies of the prevalence of osteoarthritis of knees and spine.

We should like to thank Dr. Trefor Watkins for his friendly help and guidance throughout this investigation.

\section{REFERENCES}

Heasman, M. A., Liddell, F. D. K., and Reid, D. D. (1958). Brit.

$J$. industr. Med., 15, 141.
Edmonds, O. P., (1958). M.D. Thesis, Leeds University. 